\title{
Investigating the insecticidal potential of Geomyces (Myxotrichaceae: Helotiales) and Mortierella (Mortierellacea: Mortierellales) isolated from Antarctica
}

\author{
Steven Edgington ${ }^{1 *}$, Emma Thompson $^{1}$, Dave Moore ${ }^{1}$, Kevin A Hughes ${ }^{2}$ and Paul Bridge ${ }^{1}$
}

\begin{abstract}
Fungi isolated from environmentally challenging habitats can have adaptations of potential value when developed as insect pest-controls. Fungal isolates collected from Antarctica, Geomyces sp. I, Geomyces sp. II, Mortierella signyensis and M. alpina, were investigated for (i) growth characteristics at $0-35^{\circ} \mathrm{C}$, (ii) spore production at 10 and $20^{\circ} \mathrm{C}$, (iii) viability following exposure to freezing temperatures, and (iv) insecticidal activity against waxmoths (Galleria mellonella L.), houseflies (Musca domestica L.), mealworms (Tenebrio molitor L.) and black vine weevils (Otiorhynchus sulcatus Fabricius). All isolates showed growth between $5-20^{\circ} \mathrm{C}$, with some showing growth outside this range. Geomyces isolates sporulated over a wider range of conditions than the Mortierella isolates. Spore germination at $10^{\circ} \mathrm{C}$ was higher for Geomyces sp. II when this isolate was produced at 10 compared to $20^{\circ} \mathrm{C}$ (greatest difference 74.6 vs 32.7\%). All isolates grew, with the exception of $\mathrm{M}$. alpina, following exposure to $-20^{\circ} \mathrm{C}$ for 4 weeks. Insecticidal investigations showed $M$. alpina and $M$. signyensis caused significant mortality of waxmoth and housefly larvae via injection and soil inoculation, and M. alpina caused significant mortality of housefly larvae via baiting; the Geomyces isolates had little lethal effect.
\end{abstract}

Keywords: Cold; Fungus; Biological control; Host range; Insecticide

\section{Introduction}

Sourcing insect-killing organisms from environmentally challenging habitats can uncover adaptations of value when developing these organisms as pest-control agents, e.g., cold-tolerant nematodes sourced from Scotland for black vine weevil control (Long et al. 2000) and this potential to find environmentally robust organisms has spurred an array of surveys from Sub-Saharan Africa (Shah et al. 1997) to within the polar circles (Vänninen 1996; Haukeland et al. 2006; Bridge and Worland 2008). In 2009 a project investigating cold-tolerant fungal isolates identified four strains collected from Antarctica (by British Antarctic Survey scientists) with enzyme profiles indicative of insecticidal potential (P. Bridge et al. unpublished results). The four isolates were characterised taxonomically: two were Zygomycetes in the genus

\footnotetext{
* Correspondence: s.edgington@cabi.org

'CABI UK-Centre, Bakeham Lane, Egham, Surrey TW20 9TY, UK

Full list of author information is available at the end of the article
}

Mortierella and two were Ascomycetes placed in Geomyces. Historically, most species of entomopathogenic fungi used as pest-controls are of the Ascomycete genera Beauveria, Metarhizium, Lecanicillium and Isaria (Bailey et al. 2010). The four candidates, all isolated from maritime Antarctica, showed high levels of chitinase and subtilisin proteases when grown in insect extract-based broths at low temperatures. Chitinases and subtilisins are key requirements for insecticidal activity as they provide the primary mechanisms for growth through both the exoskeleton and chitin of the insect (Clarkson et al. 1998). The psychrophilic Geomyces and Mortierella genera are widespread in Antarctic soils (Tosi et al. 2002; Hughes et al. 2003; Arenz et al. 2006) and it is likely that both genera have a role in decomposition and/or nutrient cycling; little, however, is known of their ability, if any, to kill invertebrates.

This paper investigates a number of characteristics relevant to the potential use of the four fungal isolates as 
mycoinsecticides in areas experiencing a temperate climate, including tolerance to colder temperatures and virulence against a number of common insect pests.

\section{Materials and methods}

Cultures of Geomyces sp. I (IMI 403329; BAS CC373), Geomyces sp. II (IMI 403320; BAS CC364), Mortierella signyensis (IMI 398111) and M. alpina (IMI 403255; BAS CC299) were obtained from the British Antarctic Survey Culture Collection, held at CABI, UK. Geomyces sp. I and Geomyces sp. II were isolated originally from Eucalyptus bark and pine wood baits, respectively, suspended in sea water near Rothera Research Station,

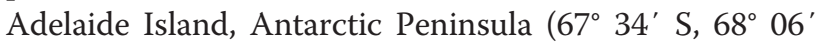
W). Mortierella signyensis and M. alpina were isolated from soil samples on Signy Island, South Orkney Islands $\left(60^{\circ} 43^{\prime} \mathrm{S}, 45^{\circ} 36^{\prime} \mathrm{W}\right)$.

\section{Temperature profiles}

Petri dishes (9 $\mathrm{cm}$ diameter) of $20 \%$ Potato Dextrose Agar (PDA) were inoculated at a central point with an upturned, non-sporulating plug (4 mm diameter) of each fungal isolate. The plugs were originally collected (using a cork-borer) from $20 \%$ PDA dishes that had been at $10^{\circ} \mathrm{C}$, in the dark, for $6 \mathrm{~d}$. The dishes were sealed with Parafilm and incubated at $0,5,10,15,20,25,30$ and $35 \pm 1^{\circ} \mathrm{C}$. Radial growth was measured every $2 \mathrm{~d}$ along two perpendicular axes which intersected at the centre of the plug. There were five dishes per isolate, at each temperature. The experiment was run for $10 \mathrm{~d}$.

\section{Spore production and germination}

Inocula for this study came from fungal cultures grown on $20 \%$ PDA for $6 \mathrm{wk}$ at $10 \pm 1^{\circ} \mathrm{C}$. Each isolate produced spores that could be harvested by scraping with a microspatula into $0.05 \%$ Tween- 80 + distilled water, with the exception of $M$. alpina which did not produce aerial spores - hence for this isolate only mycelium was used.

Petri dishes (5 cm diameter) of $20 \%$ PDA were inoculated with $40 \mu \mathrm{L}$ fungal inoculum of Geomyces sp. I, Geomyces sp. II and M. signyensis, at a spore concentration of approximately $3 \times 10^{5}$ spores $\mathrm{mL}^{-1}$, and with four equally spaced upturned mycelial plugs ( $4 \mathrm{~mm}$ diameter) of $M$. alpina. Spore inoculum was spread evenly across each dish. Dishes were sealed with Parafilm and left in darkness at 10 and $20 \pm 1{ }^{\circ} \mathrm{C}$. Every week, for $6 \mathrm{wk}$, five dishes of each isolate were harvested by scraping the surface gently with a microspatula into $0.05 \%$ Tween- 80 + distilled water (efficiency of harvesting was not determined but it is likely that the majority of spores were collected at each harvest). A spore count was done for each dish using a haemocytometer. A $50 \mu \mathrm{L}$ sample of each suspension was then inoculated onto a Petri dish ( $9 \mathrm{~cm}$ diameter) of $20 \%$ PDA to assess germination. The dish was sealed and kept in darkness at $10 \pm 1^{\circ} \mathrm{C}$ for $24 \mathrm{~h}$, after which time spore germination was assessed under a light microscope ( $\times 400$ magnification). Spores were classified as germinated if the length of the germ tube was longer than the length of the spore. When possible, at least 200 spores were counted on each dish. There were five counts per treatment (representing one count from each harvested dish).

\section{Freeze tolerance}

Geomyces spores and Mortierella plugs were used in this study. All inocula were collected from 2-wk old $20 \%$ PDA culture dishes at $10 \pm 1^{\circ} \mathrm{C}$. Spore suspensions (100 $\mu \mathrm{L}$ volume) or plugs were put into $0.5 \mathrm{~mL}$ microtubes and kept at $-20 \pm 1^{\circ} \mathrm{C}$. Samples were removed after 4 and $8 \mathrm{wk}$ then kept at room temperature for $30 \mathrm{~min}$ to defrost. Each spore suspension was spread across a $20 \%$ PDA Petri dish (9 $\mathrm{cm}$ diameter), which was then sealed and kept at $20 \pm 1^{\circ} \mathrm{C}$ for $24 \mathrm{~h}$, after which time spore germination was assessed under a light microscope $(\times 400$ magnification). Spores were classified as germinated if the length of the germ tube was longer than the length of the spore. When possible, at least 200 spores were counted on each dish. For the defrosted plugs, one plug was put upside down in the centre of a 20\% PDA Petri dish $\left(9 \mathrm{~cm}\right.$ diameter), sealed and left at $20 \pm 1^{\circ} \mathrm{C}$ for 1 wk, after which time radial growth was measured along two perpendicular axes, which intersected at the centre of the plug. Only plugs from 4 wk exposure were assessed. There were five samples (i.e., five frozen microtubes) per fungal isolate, at each time assessment, with each originating from a separate original culture dish. Running concurrently to the experiment spore suspensions of Geomyces and plugs of Mortierella were put into microtubes and left at $5 \pm 1^{\circ} \mathrm{C}$ (the laboratory standard for storage of these isolates) and assessed for germination or radial growth as above.

\section{Bioassays \\ Insect cultures}

Waxmoths (Galleria mellonella L.), houseflies (Musca domestica L.), mealworms (Tenebrio molitor L.) and black vine weevils (Otiorhynchus sulcatus Fabricius) were used in this study. Waxmoths and mealworms were obtained from Live Foods Direct, Sheffield, UK; houseflies were obtained from Davies Angling, Staines, UK and black vine weevils were obtained from various potted plants in the glasshouses at CABI, UK.

\section{Dipping}

The fungal isolates were grown on 20\% PDA culture plates ( $9 \mathrm{~cm}$ diameter) at $10 \pm 1^{\circ} \mathrm{C}$ for $2 \mathrm{wk}$. Spores of Geomyces sp. I and sp. II were harvested using a microspatula and put into $0.5 \mathrm{~mL}$ aliquots of $0.05 \%$ Tween- 80 + distilled 
water; concentrations were then adjusted to approximately $5 \times 10^{5}$ spores $/ \mathrm{mL}$. Mortierella signyensis had not produced any spores after 2 wk so approximately $25 \%$ of mycelium from each plate was harvested and put into a $0.5 \mathrm{~mL}$ aliquot of $0.05 \%$ Tween- 80 + distilled water. Mortierella alpina produced neither aerial spores nor aerial mycelium after 2 wk and was therefore excluded from this study. One late instar waxmoth larva was immersed in the fungal suspension for $5 \mathrm{~s}$, placed onto filter paper within a bioassay chamber $\left(2 \mathrm{~cm}^{3}\right)$, then incubated at $10 \pm 1^{\circ} \mathrm{C}$, in darkness. Mortality was assessed every $1-2 \mathrm{~d}$, for a maximum of $30 \mathrm{~d}$. Cadavers were removed as soon as they were found. Control larvae were immersed in $0.5 \mathrm{~mL}$ $0.05 \%$ Tween- $80+$ distilled water. Ten larvae were treated per isolate (each in a fresh fungal suspension) and the trial was done four times.

\section{Injection}

The fungal isolates were grown on $20 \%$ PDA at $10 \pm 1^{\circ} \mathrm{C}$ for a minimum of $2 \mathrm{wk}$. Spores were harvested from the dishes in $0.05 \%$ Tween- 80 + distilled water (with the exception of M. alpina - which was subsequently excluded from this trial). Pathogenicity of the isolates was tested against larval stages of waxmoth, housefly and mealworm. Each insect was injected with $10 \mu \mathrm{L}$ of fungal suspension at a concentration of approximately $1 \times 10^{6}$ spores $/ \mathrm{mL}$, using a hypodermic syringe (outer gauge diameter approximately $1 \mathrm{~mm}$ ). The insects were injected on the ventral surface, at approximately mid-body level. Control insects were injected with $10 \mu \mathrm{L}$ of $0.05 \%$ Tween$80+$ distilled water. Forty larvae were injected per isolate. The larvae were put in groups of 10 on filter paper within a Petri dish $\left(9 \mathrm{~cm}\right.$ diameter) and kept at $10 \pm 1^{\circ} \mathrm{C}$, in darkness. Larval mortality was assessed after $5 \mathrm{~d}$. The trial was done three times, with the exception of the mealworm trial which was done twice.

\section{Soil inoculation}

Mortierella signyensis and M. alpina were grown on $20 \%$ PDA at $10 \pm 1^{\circ} \mathrm{C}$ for approximately 12 wk. Petri dishes (9 $\mathrm{cm}$ diameter) were part-filled with double-sterilised (at $121^{\circ} \mathrm{C}$ for $15 \mathrm{~min}$ ) John Innes compost (ca $20 \mathrm{~g}$ per dish). Four plugs ( $4 \mathrm{~mm}$ diameter) of each isolate were put into each dish. Control dishes received four plugs of $20 \%$ PDA. Ten mid to late instar waxmoth larvae or 20 late instar housefly larvae were put into each dish. The dishes were sealed and kept at $10 \pm 1^{\circ} \mathrm{C}$, in darkness. Insect mortality was assessed after $6 \mathrm{wk}$. There were five dishes per treatment, i.e. 50-100 larvae per treatment, depending on species. The trial was done three times.

\section{Baiting}

Mortierella signyensis and M. alpina were grown on 20\% PDA at $10 \pm 1^{\circ} \mathrm{C}$ for approximately 12 wk. Petri dishes
(5 $\mathrm{cm}$ diameter) were part-filled with double-sterilised (at $121^{\circ} \mathrm{C}$ for $15 \mathrm{~min}$ ) John Innes compost (ca $10 \mathrm{~g}$ per dish). Each dish received either two double-sterilised dry cat food biscuits ('Hairball control - chicken', Hill's Pet Nutrition Inc, USA) or no biscuits. Three plugs (4 mm diameter) of each isolate were put into each dish. Control dishes received three plugs of 20\% PDA. The dishes were sealed with Parafilm and incubated at $10 \pm 1^{\circ} \mathrm{C}$. After $7 \mathrm{~d}$ five late instar housefly larvae were put into each dish, which was then re-sealed and kept at $20 \pm 1^{\circ} \mathrm{C}$ for $5 \mathrm{~d}$. The houseflies were then removed and put into empty Petri dishes $\left(5 \mathrm{~cm}\right.$ diameter) at $20 \pm 1^{\circ} \mathrm{C}$, with mortality and adult emergence assessed after 2 wk. There were five baiting dishes per fungal isolate, i.e. 25 larvae per isolate. The trial was done three times.

\section{Data analysis}

All statistical analyses were performed using Genstat 16th Edition (VSNI). Results from replicate trials were similar and were therefore combined for each fungal isolate. Percentage data (i.e. germination and mortality data) was arcsine transformed prior to analysis to improve homogeneity (the data presented here is pre-transformed data). One-way Analysis of Variance (ANOVA) with appropriate factors was used to investigate treatment effects, with Tukey's test and $t$-test used to analyse relationships and differences between means. Differences between means were considered significant at $P<0.05$.

\section{Results}

\section{Temperature profiles}

Temperature profiles for the fungal isolates are shown in Figure 1. All isolates grew at 5, 10, 15, 20 and, with the exception $M$. signyensis, $25^{\circ} \mathrm{C}$. Mortierella alpina was the only isolate with growth at $30^{\circ} \mathrm{C}$ with an extension rate of $0.8 \mathrm{~mm} \mathrm{~d}^{-1}$. There was measurable growth of both Geomyces isolates at $0^{\circ} \mathrm{C}$, but no growth for either of the Mortierella isolates. Optimal growth temperatures were approximately $25^{\circ} \mathrm{C}$ for $\mathrm{M}$. alpina and $20^{\circ} \mathrm{C}$ for the other isolates. There were significant differences between extension rates of the isolates at these optimum temperatures $(F=588.59, \mathrm{df}=3,16, P<0.05)$; the Mortierella isolates had extension rates of 3.6 to $3.7 \mathrm{~mm} \mathrm{~d}^{-1}$ at their optima, which were significantly higher than those of Geomyces sp. I and Geomyces sp. II (0.64 to $\left.0.88 \mathrm{~mm} \mathrm{~d}^{-1}\right)$.

\section{Spore production and germination}

Spore yields from cultures over time and at different temperature can be seen in Figure 2. No spores of $M$. alpina were observed at any stage of the study and spores of M. signyensis were only found on 6-wk old cultures at $10^{\circ} \mathrm{C}$. There were significant differences in yields between treatments $(F=51.06, \mathrm{df}=47,192, \quad P<0.05)$. Geomyces sp. II at $20^{\circ} \mathrm{C}$ was the first isolate to produce 


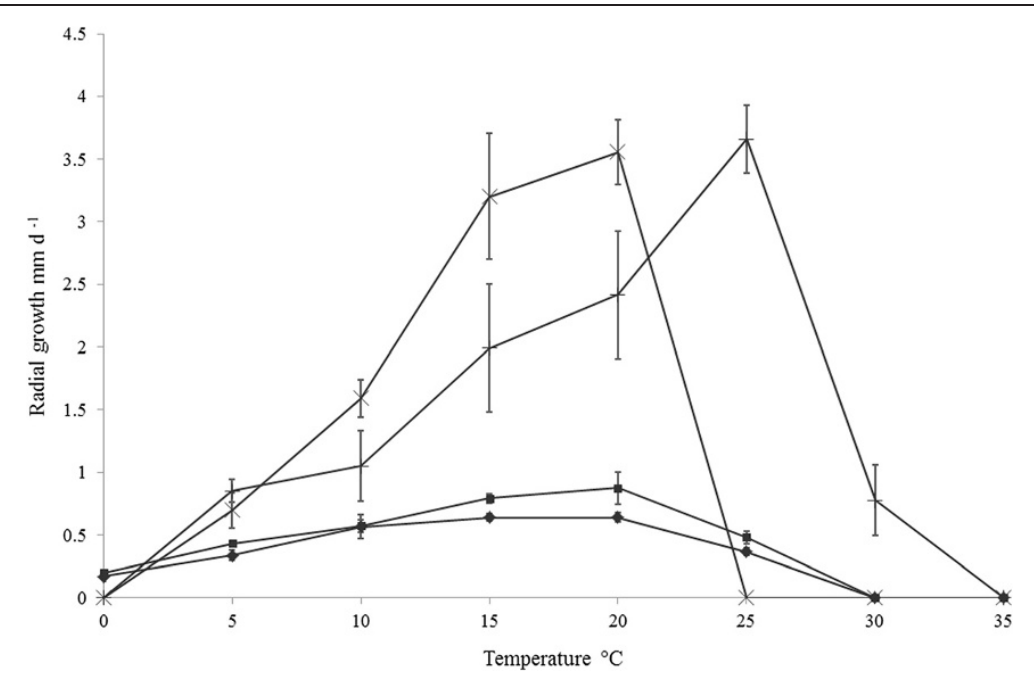

Figure 1 The effect of temperature on the growth rate of Geomyces I (IMI 403329), Geomyces II (IMI 403320), Mortierella signyensis (IMI 398111) and Mortierella alpina (IMI 403255). Vertical lines represent the 95\% confidence intervals. Geomyces sp. I; $\mathbf{m}$ : Geomyces sp. II; X: Mortierella signyensis; +: Mortierella alpina.

spores (after $1 \mathrm{wk}$ ), both Geomyces isolates produced spores after 2 wk at 10 and $20^{\circ} \mathrm{C}$. Consistently more Geomyces spores were recovered from cultures at $20^{\circ} \mathrm{C}$ compared to $10^{\circ} \mathrm{C}$. The highest yield was Geomyces sp. I after 4 wk at $20^{\circ} \mathrm{C}$, which produced a mean of $4.2 \times 10^{7}$ spores per dish (at $10^{\circ} \mathrm{C}$ this isolate yielded $3.7 \times 10^{6}$ spores per dish at $4 \mathrm{wk})$. There were significantly fewer spores from Geomyces sp. II at $20^{\circ} \mathrm{C}$ at $6 \mathrm{wk}$ vs $4 \mathrm{wk}(1.7$ vs $3.6 \times 10^{7}$ spores per dish, respectively).

Spore germination for the Geomyces isolates can be seen in Figure 3. There were significant differences in germination between treatments $(F=44.15, \mathrm{df}=11,48$, $P<0.05)$. Germination of Geomyces sp. II was significantly higher than Geomyces sp. I at each time and for each temperature (ranging from 29-75\%) whilst Geomyces sp. I did not exceed $12 \%$ germination. Spores of Geomyces sp. II produced at $10^{\circ} \mathrm{C}$ had significantly higher germination at $10^{\circ} \mathrm{C}$ than those produced at $20^{\circ} \mathrm{C}$, with the greatest difference being 75 vs 33\% (for spores from 2-wk old dishes). Spores of Geomyces sp. I produced at 10 and $20^{\circ} \mathrm{C}$ had similar germination levels at $10^{\circ} \mathrm{C}$.

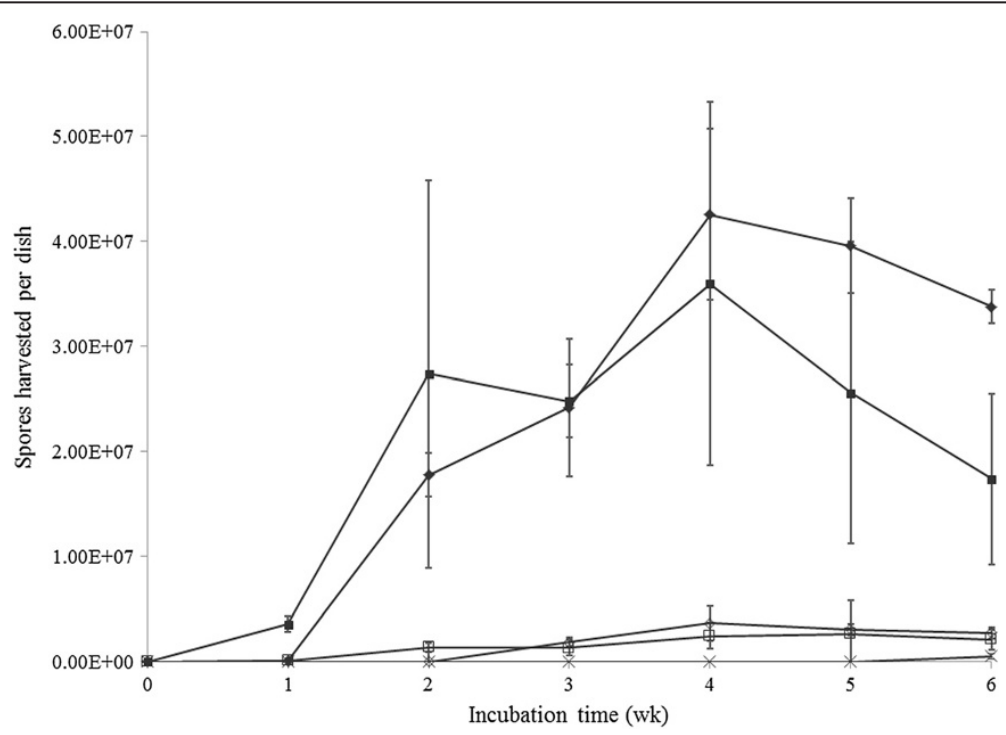

Figure 2 Spore harvests of Geomyces I (IMI 403329), Geomyces II (IMI 403320), Mortierella signyensis (IMI 398111) and Mortierella alpina (IMI 403255) from culture dishes at 10 and $20 \pm 1^{\circ} \mathrm{C}$ for 6 wk. Vertical lines represent the $95 \%$ confidence intervals. $20^{\circ} \mathrm{C}$ Geomyces sp. I; a: $20^{\circ} \mathrm{C}$ Geomyces sp. II; ×: $10^{\circ} \mathrm{C}$ Mortierella signyensis; ৩: $10^{\circ} \mathrm{C}$ Geomyces sp. I; $\square: 10^{\circ} \mathrm{C}$ Geomyces sp. II. 


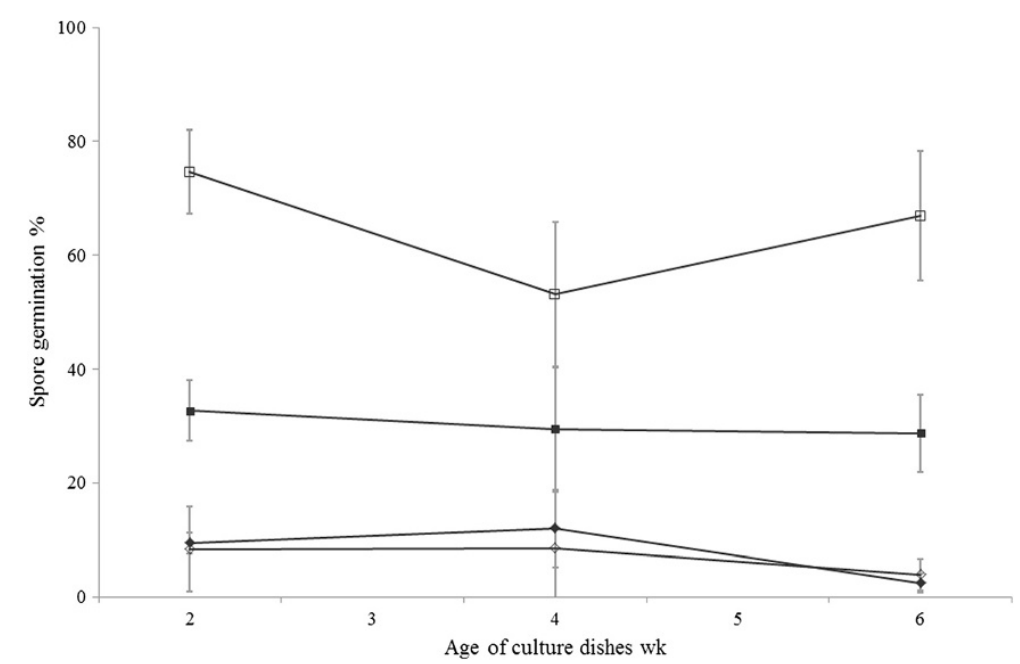

Figure 3 Spore germination of Geomyces I (IMI 403329) and Geomyces II (IMI 403320) harvested from dishes at 10 and $20 \pm 1^{\circ} \mathrm{C}$ and of different ages. Vertical lines represent the $95 \%$ confidence intervals. $\diamond: 10^{\circ} \mathrm{C}$ Geomyces sp. I; $\square: 10^{\circ} \mathrm{C}$ Geomyces sp. II; $20^{\circ} \mathrm{C}$ Geomyces sp. I; $\mathbf{m}: 20^{\circ}$ C Geomyces sp. II.

\section{Freeze tolerance}

Germination of Geomyces sp. I and Geomyces sp. II following exposure to -20 and $5^{\circ} \mathrm{C}$ can be seen in Table 1 . There were significant differences in the germination of both isolates following exposure to $-20^{\circ} \mathrm{C}$ for $4 \mathrm{wk}$ (Geomyces sp. I: $F=214.2, \mathrm{df}=2,12, P<0.05$; Geomyces sp. II: $F=142.1$, df $=2,12, P<0.05$ ); falling from 89.5 to $17.0 \%$ and 97.4 to $40.7 \%$ after $4 \mathrm{wk}$ at $-20^{\circ} \mathrm{C}$, for Geomyces sp. $\mathrm{I}$ and sp. II, respectively. After 8 wk at $-20^{\circ} \mathrm{C}$ germination of Geomyces sp. I had fallen to $4.7 \%$; there was no further reduction in the germination of Geomyces sp. II. Germination of both isolates was $>96 \%$ after 8 wk at $5^{\circ} \mathrm{C}$. There were significant differences in radial growth of $M$. signyensis and $M$. alpina following exposure to -20 and $5^{\circ} \mathrm{C}(F=58.6, \mathrm{df}=3,36, P<0.05)$, both isolates had significantly lower levels of growth following
4 wk at $-20^{\circ} \mathrm{C}$ vs $5^{\circ} \mathrm{C}(M$. signyensis: $t=4.37, \mathrm{df}=18, P<$ 0.05 ; $M$. alpina: $t=3.48, \mathrm{df}=18, P<0.05)$. Radial growth of $M$. signyensis totalled $12.2 \pm 0.5 \mathrm{~mm}$ following $-20^{\circ} \mathrm{C}$ exposure, compared to $20.7 \pm 0.9 \mathrm{~mm}$ at $5^{\circ} \mathrm{C}$; there was no growth of $M$. alpina after exposure to $-20^{\circ} \mathrm{C}$, compared to $15.2 \pm 1.5 \mathrm{~mm}$ at $5^{\circ} \mathrm{C}$.

\section{Bioassays \\ Dipping}

Mortality from the dipping study can be seen in Table 2 . There were no significant differences in waxmoth mortality between treatments, including controls $(F=3.18$, $\mathrm{df}=3,15, P>0.05)$, with mortality ranging from $13(M$. signyensis) to $35 \%$ (Geomyces I). Time until death was not significant between treatments $(F=0.38, \mathrm{df}=3,15$,

Table 1 Spore germination of Geomyces I (IMI 403329) and Geomyces II (IMI 403320) and vegetative radial growth of Mortierella signyensis (IMI 398111) and Mortierella alpina (IMI 403255) following storage at -20 and $5 \pm 1^{\circ} \mathrm{C}$, for 0 to 8 weeks (mean $\pm \mathrm{SE})$

\begin{tabular}{|c|c|c|c|c|c|}
\hline \multirow[t]{2}{*}{ Isolate } & \multirow[t]{2}{*}{ Temperature $\left({ }^{\circ} \mathrm{C}\right)$} & \multicolumn{3}{|c|}{ Germination $\%$ (mean $\pm \mathrm{SE}$ ) } & \multirow{2}{*}{$\begin{array}{c}\text { Radial growth } \mathrm{mm} \text { (mean } \pm \mathrm{SE} \text { ) } \\
4 \mathrm{wk}\end{array}$} \\
\hline & & 0 wk & 4 wk & 8 wk & \\
\hline \multirow[t]{2}{*}{ Geomyces I } & 5 & $89.5 \pm 1.2^{a}$ & $83.4 \pm 1.8^{a}$ & $97.8 \pm 0.6^{b}$ & \\
\hline & -20 & $89.5 \pm 1.2^{a}$ & $17.0 \pm 3.5^{b}$ & $4.7 \pm 2.4^{c}$ & \\
\hline \multirow[t]{2}{*}{ Geomyces II } & 5 & $97.4 \pm 1.2^{a}$ & $90.7 \pm 1.6^{b}$ & $99.4 \pm 0.3^{a}$ & \\
\hline & -20 & $97.4 \pm 1.2^{a}$ & $40.7 \pm 3.7^{b}$ & $45.2 \pm 4.2^{b}$ & \\
\hline \multirow[t]{2}{*}{ Mortierella signyensis } & 5 & & & & $20.7 \pm 0.9^{a}$ \\
\hline & -20 & & & & $12.2 \pm 0.5^{b}$ \\
\hline \multirow[t]{2}{*}{ Mortierella alpina } & 5 & & & & $15.2 \pm 1.5^{\mathrm{a}}$ \\
\hline & -20 & & & & $0 \pm 0^{b}$ \\
\hline
\end{tabular}

For each Geomyces isolate, figures with the same letter within each row are not significantly different; for each Mortierella isolate, figures with the same letter within each column are not significantly different $(P>0.05)$. 
Table 2 Mortality of waxmoth (Galleria mellonella), housefly (Musca domestica), mealworm (Tenebrio molitor) and black vine weevil (Otiorhynchus sulcatus) larvae following inoculation with fungal isolates Geomyces I (IMI 403329), Geomyces II (IMI 403320), Mortierella signyensis (IMI 398111) and Mortierella alpina (IMI 403255)

\begin{tabular}{|c|c|c|c|c|c|c|}
\hline \multirow[t]{2}{*}{ Inoculation } & & \multirow[t]{2}{*}{ Isolate } & \multicolumn{4}{|c|}{ Mortality\%* } \\
\hline & & & Galleria mellonella & Musca domestica & Tenebrio molitor & Otiorhynchus sulcatus \\
\hline \multirow{4}{*}{\multicolumn{2}{|c|}{ Dipping }} & Geomyces I & $35.0 \pm 8.7^{\mathrm{a}}$ & - & - & - \\
\hline & & Geomyces II & $32.5 \pm 4.8^{\mathrm{a}}$ & - & - & - \\
\hline & & Mortierella signyensis & $12.6 \pm 6.3^{\mathrm{a}}$ & - & - & - \\
\hline & & control & $20.0 \pm 4.1^{\mathrm{a}}$ & - & - & - \\
\hline \multirow{4}{*}{\multicolumn{2}{|c|}{ Injection }} & Geomyces I & $8.3 \pm 3.3^{\mathrm{a}}$ & $29.2 \pm 6.8^{\mathrm{a}}$ & $10.0 \pm 2.4^{\mathrm{a}}$ & - \\
\hline & & Geomyces II & $1.7 \pm 1.2^{\mathrm{ab}}$ & $26.7 \pm 6.5^{\mathrm{a}}$ & $8.8 \pm 2.0^{\mathrm{a}}$ & - \\
\hline & & Mortierella signyensis & $94.2 \pm 2.8^{c}$ & $62.5 \pm 7.4^{\mathrm{b}}$ & $67.5 \pm 4.1^{\mathrm{b}}$ & - \\
\hline & & control & $5.0 \pm 3.2^{\mathrm{ab}}$ & $15.0 \pm 3.9^{a}$ & $7.5 \pm 2.2^{\mathrm{a}}$ & - \\
\hline \multirow{3}{*}{\multicolumn{2}{|c|}{ Soil }} & Mortierella signyensis & $0.4 \pm 6.1^{\mathrm{a}}$ & $38.3 \pm 3.0^{\mathrm{a}}$ & - & $6.0 \pm 3.1^{\mathrm{a}}$ \\
\hline & & Mortierella alpina & $50.7 \pm 9.8^{b}$ & $33.0 \pm 4.4^{a}$ & - & $2.0 \pm 2.0^{a}$ \\
\hline & & control & $0.8 \pm 0.6^{a}$ & $33.7 \pm 0.7^{a}$ & - & $12.0 \pm 6.1^{a}$ \\
\hline \multirow[t]{3}{*}{ Baiting } & food & Mortierella signyensis & - & $34.7 \pm 7.1^{\mathrm{ab}}$ & - & - \\
\hline & & Mortierella alpina & - & $50.7 \pm 7.1^{\mathrm{b}}$ & - & - \\
\hline & & control & - & $25.3 \pm 9.3^{\mathrm{ab}}$ & - & - \\
\hline \multirow[t]{3}{*}{ Baiting ${ }^{* *}$} & no food & Mortierella signyensis & - & $6.7 \pm 1.3^{\mathrm{a}}$ & - & - \\
\hline & & Mortierella alpina & - & $9.3 \pm 5.3^{\mathrm{a}}$ & - & - \\
\hline & & control & - & $8.0 \pm 4.6^{\mathrm{a}}$ & - & - \\
\hline
\end{tabular}

- = trial not done for this species; ${ }^{*}$ mortality of Musca domestica was a function of non-emergence from puparia; ${ }^{*}$ insects exposed to soil + fungus, with absence of food source (final fungal load may differ between dishes).

Inoculation was via dipping, injection, soil treatment and baiting. All trials were run at $10^{\circ} \mathrm{C}$. Mortality was assessed after $5 \mathrm{~d}$ for injected insects and 4 wk for soil inoculation. For each insect and for each inoculation method, figures with the same letter within each column are not significantly different $(P>0.05)$.

$P>0.05)$, ranging from a mean of $( \pm$ S.E. $) 17( \pm 4.5)$ to 23 $( \pm 1.6)$ d, from control to Geomyces 1 , respectively.

\section{Injection}

Results from the injection bioassay can be seen in Table 2. There were significant differences in mortality between fungal treatments for waxmoths $(F=138.06$, $\mathrm{df}=4,55, P<0.05)$, flies $(F=9.08, \mathrm{df}=4,55, P<0.05)$ and mealworms $(F=29.66, \mathrm{df}=4,35, P<0.05)$. Mortierella signyensis caused significant waxmoth, housefly and mealworm mortality, ( $v s$ control mortality) at 94.2 ( $v s 5)$, 62.5 (vs 15) and 67.5 (vs 7.5)\% mortality for waxmoths, houseflies and mealworms, respectively; the other isolates caused no significant insect mortality.

\section{Soil inoculation}

Results from the soil inoculation bioassay can be seen in Table 2. There were significant differences in waxmoth mortality between treatments $(F=53.36$, df $=2,42, P<$ 0.05). Mortierella alpina caused significant waxmoth mortality, at $50.7 \%$ vs $<1 \%$ (control), M. signyensis had no effect on mortality. There were no significant differences in housefly mortality between treatments $(F=0.83$, $\mathrm{df}=2,42, P>0.05)$, mortality ranged from 33 to $38.3 \%$.
There were no significant differences in black vine weevil mortality $(F=1.43, \mathrm{df}=2,27, \quad P>0.05)$, mortality ranged from 2 to $12 \%$.

\section{Baiting trial}

Results from the baiting trial can be seen in Table 2 . There were no significant differences in housefly mortality (as a function of non-emergence from puparia) between treatments for the food trial, and also the no food trial (food: $F=1.55$, df $=2,42, P>0.05$; no food: $F=0.05$, $\mathrm{df}=2,42, P>0.05)$. When results from the food and no food trials were analysed together $(F=5.84, \mathrm{df}=5,84$, $P<0.05)$ there was a significant difference in housefly mortality between $M$. alpina food and $M$. alpina no food, at 50.7 vs $9.3 \%$, respectively.

\section{Discussion}

Surveys of Antarctic soils have revealed a number of fungal genera that have shown insecticidal activity in other environments, including the entomopathogenic hyphomycetes Lecanicillium lecanii and Beauveria bassiana (Mahaney et al. 2001; Hughes et al. 2003; see also http://www.antarctica.ac.uk/bas_research/data/access/ fungi). Whilst there is no history of Geomyces and 
Mortierella killing insects, species of Mortierella have been investigated as potential biological control agents against bacterial and oomycete plant pathogens (Tagawa et al. 2010; Lambe and Wills 1983) and some Antarctic strains of $M$. alpina have been shown to exhibit antimicrobial activity (Melo et al. 2013).

In the present study, M. alpina produced neither aerial spores nor aerial mycelium; only vegetative growth was observed which was always under the surface of the culture media. Therefore, bioassay results from $M$. alpina are not directly comparable with the other strains that did produce spores. In contrast, the Geomyces isolates produced abundant spores; although of course quantity of spores is not the only factor of importance when developing a mycoinsecticide, as spore quality (persistence, viability, etc.,) is also critical for success (Magan 2001). All isolates grew at $5^{\circ} \mathrm{C}$ and both Geomyces grew at $0^{\circ} \mathrm{C}$, a reflection of the cold climatic conditions where the isolates were collected e.g., soil temperatures on Signy Island are typically below $0^{\circ} \mathrm{C}$ for around nine months of the year (Chambers 1966) (although the Geomyces were isolated from the sea sampling). Furthermore, three of the isolates grew after four weeks exposure to $-20^{\circ} \mathrm{C}$. Cold tolerance may be of particular relevance to the use of fungi against insect pests in temperate climates as some larvae cause considerable damage to plants during winter months. None of the isolates grew at $30^{\circ} \mathrm{C}$ and above, although some strains showed tolerance to incubation at $35^{\circ} \mathrm{C}$. For outdoor use in temperate climates, lower temperature limit is one of the principal environmental constraints to most, if not all, existing mycoinsecticide fungi (e.g., Beauveria and Metarhizium) (Inglis et al. 2001). Whilst many of these fungal groups are mesophilic, and grow between $10-40^{\circ} \mathrm{C}$, they may only produce significant growth between $18-30^{\circ} \mathrm{C}$ (Rangel et al. 2005). If temperatures go outside this range and fungal growth is reduced as a result, then infection by the pathogens may not occur. Temperature constraints can, to some degree, be obviated by formulation (Langewald et al. 1999) and by modifying culture conditions to change spore physiology (Lane et al. 1991). In the present study, spores of Geomyces sp. II germinated consistently better at $10^{\circ} \mathrm{C}$ when they were grown at $10^{\circ} \mathrm{C}$, compared to those grown at $20^{\circ} \mathrm{C}$. A number of studies have shown that depleted resources and abiotic stresses during the production process, including exposure to thermal extremes, can lead to increased levels of endogenous compounds such as trehalose, glycerol and erythritol, which allow metabolic activity of the organisms to remain unaffected at times of sub-optimal environmental conditions (Crowe et al. 1984; Hallsworth and Magan 1994; Davis et al. 2000). In the present study, the improved germination of spores at cooler conditions when isolates were cultured at $10 \mathrm{vs} 20^{\circ} \mathrm{C}$, may be a consequence of placing the fungus under thermal stress.
The natural host range of the test isolates (if indeed they do kill in nature, as opposed to being opportunistic degraders of already dead invertebrates) is unknown as they were obtained directly from soil and marine samples. Both genera are known to be widespread in the Antarctic, particularly in soil; Mortierella species have been reported in association with Antarctic invertebrates (Bridge and Denton 2007) and the isolate of M. signyensis used in the present study was derived from such samples. Coprophilous Zygomycetes have been isolated from insect cadavers in the sub-Antarctic (Bridge et al. 2008) and a novel species of Arthrobotrys capable of trapping springtails has been described from the maritimeAntarctic (Onofri and Tosi 1992). It would seem likely that a number of fungal/invertebrate associations may occur normally in the Antarctic environment. It is possible that the M. signyensis isolate of the present study may have insect-killing properties as waxmoths, houseflies and mealworms all had higher levels of mortality, compared to the controls, when injected with this isolate. Furthermore, waxmoths in soil that contained $M$. alpina also died. There appeared to be no contact action of the isolates on houseflies, but the baiting studies suggested that at least one isolate ( $M$. alpina) could kill, if ingested. However, caution is needed when interpreting these results regarding insecticidal potential as facilitating the introduction of the fungus into the host viz injecting it, negates an important component of insecticidal activity, namely breaching the insect's integument. Hyphomycetous fungi can cause insect death by depleting insect nutrients, by physical obstruction and by toxicosis (or a combination of all three) but it is not known how M. alpina and $M$. signyensis caused insect death. The presence of chitinases and subtilisin proteases (discovered during a previous study) may indicate an ability to penetrate the insect cuticle, which could facilitate pathogenesis. Fatty acids have a long history as insecticidal agents (e.g. Tattersfield and Gimingham 1927) and some strains of Mortierella produce significant amounts of fatty acids. Mortierella alpina is used for the commercial production of archidonic acid, an omega- 6 fatty acid with antimicrobial properties (Huang et al. 2010) and such compounds could provide a further potential insecticidal process.

This study has examined the physiology of four fungal isolates obtained from the Antarctic region and their ability to kill insects. Mortierella signyensis showed significant kill of insects from three orders and significant kill was also shown via two methods of delivery. The mechanisms of kill, however, are not known, but do not appear to correspond with those of more conventional entomopathogenic genera such as Metarhzium. It is unclear whether any of the isolates may be of value as a lowtemperature mycoinsecticide, however, the environmental 
characteristics of their geographical origin may make Antarctica a potential source of fungi for biological control or other biotechnological applications.

\section{Competing interest}

The authors declare that they have no competing interests.

\section{Authors' contribution}

SE and ET carried out the profiling studies. SE drafted the manuscript. All authors read and approved the final manuscript.

\section{Acknowledgements}

The authors wish to thank Belinda Luke for reviewing a late draft of the manuscript. This study was possible through on-going activities at CABI UK-Centre, supported by the Natural Environmental Research Council (NERC) (award number MYIP $719 \mathrm{InnB}$ ) and the British Antarctic Survey (BAS) Polar Science for Planet Earth (PSPE) programme.

\section{Author details}

${ }^{1}$ CABI UK-Centre, Bakeham Lane, Egham, Surrey TW20 9TY, UK. ${ }^{2}$ British Antarctic Survey, Natural Environment Research Council, High Cross, Madingley Road, Cambridge CB3 OET, UK.

Received: 29 May 2014 Accepted: 2 June 2014

Published: 9 June 2014

\section{References}

Arenz BE, Held BW, Jurgens JA, Farrell RL, Blanchette RA (2006) Fungal diversity in soils and historic wood from the Ross Sea Region of Antarctica. Soil Biol Biochem 38:3057-3064

Bailey A, Chandler D, Grant WP, Greaves J, Prince G, Tatchell M (2010) Biopesticides pest management and regulation. CABI Publishing, Oxon

Bridge PD, Denton G (2007) Isolation of diverse viable fungi from the larvae of the introduced chironomid Eretmoptera murphyi on Signy Island. Polar Biol 30:935-937

Bridge PD, Worland MR (2008) An association between the Antarctic mite Alskozetes antarcticus (Michael) and an entomophthoralean fungus of the genus Neozygites Witlaczil. Exp Appl Acarol 46:43-52

Bridge PD, Hughes KA, Denton JO (2008) Association of the coprophilous fungus Pirella circinans with an indigenous beetle on the sub-Antarctic Bird Island. Polar Biol 31:657-661

Chambers MJG (1966) Investigation of patterned ground at Signy Island, South Orkney Islands. II - Temperature regimes in the active layers. Br Antarct Surv Bull 10:71-83

Clarkson J, Screen S, Bailey A, Cobb B, Charnley K (1998) Fungal pathogenesis in insects. In: Bridge P, Couteaudier Y, Clarkson J (eds) Molecular variability of fungal pathogens. CABI publishing, Oxon, pp 83-94

Crowe JH, Crowe LM, Chapman D (1984) Preservation of membranes in anhydrobiotic organisms: the role of trehalose. Science 223:701-703

Davis DJ, Burlak C, Money NP (2000) Osmotic pressure of fungal compatible osmolytes. Mycol Res 104:800-804

Hallsworth JE, Magan N (1994) Improved biological control by changing polyols/trehalose in conidia of entomopathogens. In: Brighton crop protection conference-pests and diseases, British Crop Protection Council, Farnham., pp 1091-1096

Haukeland S, Klingen I, Brurberg MB (2006) An overview of entomopathogenic nematodes in the Nordic countries including a first report of Steinernema carpocapsae (Steinernematidae: Rhabditida). Russ J Nematol 14:139-146

Huang CB, George B, Ebersole JL (2010) Antimicrobial activity of n-6, n-7 and n-9 fatty acids and their esters for oral microorganisms. Arch Oral Biol 55:555-560

Hughes KA, Lawley B, Newsham KK (2003) Solar UV-B radiation inhibits the growth of Antarctic terrestrial fungi. Appl Environ Microbiol 69:1488-1491

Inglis GD, Goettel MS, Butt TM, Strasser H (2001) Use of Hyphomycetous fungi for managing insect pests. In: Butt TM, Jackson CW, Magan N (eds) Fungi as biocontrol agents; progress, problems and potential. CABI Publishing, Oxon, pp 23-69

Lambe RC, Wills WH (1983) Fungicides and Mortierella for the protection of azaleas from Phytophthora root rot. Phytopathology 73:503, Abstr
Lane BS, Trinci APJ, Gillespie AT (1991) Influence of cultural conditions on the virulence of conidia and blastospores of Beauveria bassiana to the green leafhopper, Nephotettix virescens. Mycol Res 95:829-833

Langewald J, Ouambama Z, Mamadou A, Peveling R, Stolz I, Bateman R, Attignon S, Blanford S, Arthurs S, Lomer C (1999) Comparison of an organophosphate insecticide with a mycoinsecticide for the control of Oedaleus senegalensis (Orthoptera: Acrididae) and other Sahelian grasshoppers at an operational scale. Biocontrol Sci Tech 9:199-214

Long SJ, Richardson PN, Fenlon JS (2000) Influence of temperature on the infectivity of entomopathogenic nematodes (Steinernema and Heterorhabditis spp.) to larvae and pupae of the vine weevil Otiorhynchus sulcatus (Coleoptera: Curculionidae). Nematology 2:309-317

Magan N (2001) Physiological approaches to improving the ecological fitness of fungal biocontrol agents. In: Butt TM, Jackson CW, Magan N (eds) Fungi as biocontrol agents; progress, problems and potential. CABI Publishing, Oxon, pp 239-251

Mahaney WC, Dohm JM, Baker VR, Newsom HE, Malloch D, Hancock RGV, Campbell I, Sheppard D, Milner MW (2001) Morphogenesis of Antarctic paleosols: Martian analogue. Icarus 154:113-130

Melo IS, Santos SN, Rosa LH, Parma MM, Silva L, Queiroz SCN, Pellizari VH (2013) Isolation and biological activities of an endophytic Mortierella alpina strain from the Antarctic moss Schistidium antarctici. Extremophiles 18:15-23

Onofri S, Tosi S (1992) Arthrobotrys ferox sp. nov. a springtail-capturing hyphomycete from continental Antarctica. Mycotaxon 44:445-451

Rangel DEN, Braga GUL, Anderson AJ, Roberts DW (2005) Variability in conidial thermotolerance of Metarhizium anisopliae isolates from different geographic origins. J Invertebr Pathol 88:116-125

Shah PA, Kooyman C, Paraïso A (1997) Surveys for fungal pathogens of locusts and grasshoppers in Africa and the Near East. In: Goettel MS, Johnson DL (eds) Microbial control of grasshoppers and locust. Memoirs of the Entomological Society of Canada 171, Ontario, pp 27-35

Tagawa M, Tamaki H, Manome A, Koyama O, Kamagata Y (2010) Isolation and characterization of antagonistic fungi against potato scab pathogens from potato field soils. FEMS Microbiol Lett 305:136-142

Tattersfield F, Gimingham CT (1927) Studies on contact insecticides. Ann Appl Biol 14:331-358

Tosi S, Casado B, Gerdol R, Caretta G (2002) Fungi isolated from Antarctic mosses. Polar Biol 25:262-268

Vänninen I (1996) Distribution and occurrence of four entomopathogenic fungi in Finland: effect of geographical location, habitat type and soil type. Mycol Res 100:93-101

\section{doi:10.1186/2193-1801-3-289}

Cite this article as: Edgington et al:: Investigating the insecticidal potential of Geomyces (Myxotrichaceae: Helotiales) and Mortierella (Mortierellacea: Mortierellales) isolated from Antarctica. SpringerPlus 2014 3:289

\section{Submit your manuscript to a SpringerOpen ${ }^{\odot}$ journal and benefit from:}

- Convenient online submission

- Rigorous peer review

- Immediate publication on acceptance

- Open access: articles freely available online

- High visibility within the field

- Retaining the copyright to your article

Submit your next manuscript at springeropen.com 